\title{
Aspects, Impediments and Prospects of South Asian Association of Regional Cooperation (SAARC)
}

\author{
Anila Sultana \\ Lecturer, Department of Economics, \\ Federal Urdu University of Arts, Sciences and Technology \\ Karachi-Pakistan \\ anilasultana@fuuast.edu.pk \\ Qaiser Sharif \\ Lecturer, Department of Humanities, \\ Nazir Hussain University, \\ Karachi-Pakistan \\ qaiser.sharif@nhu.edu.pk
}

\begin{abstract}
Combined with common features such as historical context, geographical proximity, common characteristics of social and political values, the amount of material and human resources inspired the recognition of the South Asian block known as SAARC (South Asian Association of Regional Cooperation). The SAARC sanction plots alluring objectives and goals that are intended to advance nearer trade, economic, cultural, and social relations in South Asia. The association has passed a few goals and archives to seek after these destinations. This regional alliance has a great deal of potential for advancing trade, economic relations, education, travel industry, health care, women empowerment, terrorism, human development, communication, and agriculture development. The key concept behind this co-operational of regional partners was the extension of commercial, political, and social collaboration, a shared understanding of the region's tacit use, and persistence in countering threats. The paper discusses the extent to which SAARC
\end{abstract}


has contributed to increased cooperation between South Asian countries, while at the same time presenting recommendations to improve potential ties between these nations.

Keywords: SAARC, Trade Relationships, Pakistan, Regional cooperation

\section{Introduction}

South Asia's persistent legacies of colonial history; uncontrolled human and distinct movements through fragile, porous, fractured borders; intra-territorial economic disparities; ethnic and spiritual differences; and consequent bilateral conflicts were hardly any components of SAARC's adjournment base until 1985. Its constitution removed "bilateral and controversial issues" from its platform as a security clause (The News, 2007).

The concern of accord and wellbeing through successful regional and universal in tegration has to turn into a vital factor in the particular days. The stability and progress of any country today isn't appraised as far as combatant and defense capabilities yet regarding how a community can flourish investments, trade relations, and economic integration inside the region and internationally as well (Tonnesson, 2004).

The influence of this value of regionalism in Southern Asia can be seen in the evolution of SAARC. The principle idea behind this alliance was the expansion of economic, political, and social cooperation, a common view for using the implicit of the region and persistence to counter threats. The general assessment of the alliance shows not extremely pessimistic impressions regardless of the evidence that fruitless in assured disciplines but underlines the imperative to work together elsewhere by relaxing all exceptional debates encompassed by the representative countries and building understanding on secure commitment.

\section{Historical Background}


SAARC was formed on the $8^{\text {th }}$ of December 1985. It has its head office in Kathmandu, the city of Nepal. On May 2, 1980, the late leader of Bangladesh, Ziaur Rahman, shaped the very first suggestion to set up a structure for regional integration in the South Asian territory. Preceding this, at least three conferences addressed the concept of South Asian integration: the Colombo Powers Conference held in April 1954, the Asian Relations Session in New Delhi organized in April 1947and the Baguio Symposium in the Philippines in May 1950 (Rehman, 1999).

The governments of Bangladesh, Pakistan, Bhutan, the Maldives, Sri Lanka, Nepal, and India have formally adopted a charter to promote cultural, social, and economic development in the South Asian territory, as well as to promote cooperation and friendship with the rest of developing economies. Meetings of heads of state were routinely hung on year-on-year principle. In the last twenty-six years, due to the cooperation and cooperative efforts being made by the Member States, SAARC has made enormous changes. SAARC's growth and development over the last few years can be viewed under the subsequent headings. Since the creation of the Sothern block in 1985, the degree of participation between the representative communities has improved significantly (Kripa, 2008). Throughout the ongoing years, realizing the significance of development and regional support, SAARC representatives have now formed a sense of boosting territorial economic advancements and they advocate recovery of the association by stirring from simply the circulation of announcements to functional execution of the strategies and approaches to transform this frail bloc into a conceivably evolved one. Likewise, this appreciation has contributed to an increase in the pace of cooperation between the participants. This partnership can be observed in the creation and launch of different programs and communal welfares. These include the formation of the South Asia Foundation, SAARC International College, Bangladesh, South Asian University, New Delhi, SAARC Writers, and Literature Foundation, and South Asia Centre for Policy Studies.

\section{SAARC's Impact on Regional Economy and Trade}

Trade liberalization and facilitation are very important for the success of SAARC, and the first most to be concentrated on is the growth of South Asia. At least several 
years of discussions have laid the groundwork for cooperation in this particular field. SAARC addressed the Preferential Trading Area (SAPTA) midst the member republics during the 1990s, which materialized in the form of the Free Trade Agreement, now identified as the South Asian Free Trade Agreement. Under this agreement, the tariff reduction strategy was outlined and this reduction was executed in two phases since 2006. That is India and Pakistan enforced to reduce tariffs on all commodities to twenty percent within two years and to thirty percent on all other countries within three years (Hussain, Islam \& Kibra, 1999). Pakistan and India agreed in the second phase to reduce tariffs on commodities to 0-5 percent within three years. While there have been a lot of complications with the measures taken to trade freely in the region to boost cooperation and regional growth (The News, 2004).

\section{Upsurge in External Support}

It is stigmatizing that the members of SAARC do not grow every portion of their economies alone. They are requiring sponsorship and help with education, funds, resources, energy, and upheaval from the further developed economies. One of the constructive areas of emphasis in the years continuing has been the interest of the further developed countries in the southern region who need to give succor in economic and social fields. The member nations have arrived at the resolution during the years continuing that they would invite any relief from the onlooker nation-states and being spectators, China, USA, South Korea, Japan, EU, China, and Iran are eager to grant relief. For instance, Japan has granted aid in disaster management and social framework development, China granted contribution to South Asian Development Fund and the continuing help has additionally instigated from China to maintain the China-South Asia forum of business (Dash, 1996). SAARC has set up institutionalized tactics for sharing with numerous new territorial federations and worldwide and regional alliances. The organization has likewise been currently settling on MOUs and agreements with the remaining worldwide as well as regional organizations like United Nations International Children Education Fund (UNICEF), International Telecommunications Union (ITU), United Nations Development Program (UNDP), United Nations Drug 
Control Program (UNDCP), United Nations Conference on Trade and Development (UNCTAD), Asia Pacific Tele community (APT). This outside help gives a lift to the focuses and objective of the southern sub-continent to push in advance for a better future in the financial and social fields and it is moreover a nice open entryway for the people to make between state investments inside SAARC.

\section{Social Solidarity between Members}

One of SAARC's most important goals is to improve the interaction between people and individuals. Although it is very strenuous to establish an atmosphere for open collective communication in the presence of a large-scale institutional setup, the representative States have realized the value of this feature of teamwork in recent years, then as a consequence of this thought, SAARC has certified to launch a wellconnected South program and it can be so if individuals for whom such steps have been taken such as SAARC Documentation Centre, Scheme for Promotion of Organized Tourism, chairs, Fellowship and Scholarship Schemes, Chamber of Commerce and Industry, Youth Volunteer Programme and South Asian Festivals. Also, civic institutions in SAARC member countries are seeking to develop more networks of contact between retired military and civil officials, academics, scholars, journalists. One of the aspects affected by this large aim of regional growth is also the progress of Track II diplomacy between India and Pakistan. "According to Former Indian Prime Minister I. K. Gujral, I have the increasing feeling that un-official SAARC is going to be the driving force behind the official SAARC. This is some sort of New Regionalism which is engulfing the entire South Asian region." (Bhargava \& Lama, 2008).

\section{Cooperation on Terrorism and Defence}

In 1987, the "SAARC Convention" on the intense of crime was marked and the additional covenant on violence was later signed. This was in line with verdict 1373 of the United Nations Security Council. After much debate and discussion regarding the concept of terrorism, the other decorum on violence was adopted in 2005. Despite these two important documents on terrorism, there has been little 
support for collaboration on the topic of terrorist violations. Disregarding these two significant archives on illegal intimidation, there has not been a lot of eagerness to participate in matters of rebel attack and subsidizing within the part nations. Participation has been restricted to bilateral dynamism. The two monitoring desks SAARC Drug Offences Monitoring Desk (SDOMD), Colombo, Sri Lanka, and SAARC Terrorist Offences Monitoring Desk (STOMD), Colombo, Sri Lanka are formed (Lama, 2006).

\section{Emphasis on Youth Development}

In the vast majority of non-industrial nations, youth is disregarded. Even though adolescent structures a significant piece of advancement for any country yet they are not referred to while captivating significant approach choices. Given the reasonable section old enough inside which youngsters drop, they are profoundly hazarding taking and in the event of no open doors for evolution, they're also becoming the cause of collapsing regimes. SAARC individuals have an expanding pace of the youthful populace and they should be completed the focal point of consideration which the bloc has reflected on.

The SAARC teen's verdict is granted to extraordinary people in the territory. The honor is eminent because of the acknowledgment it provides for the Award victor in the SAARC area. This depends on explicit subjects administer every year. It perceives and advances the responsibility and ability of the adolescent who offer back to the universe everywhere through different activities (The Nation, 1999).

\section{Starvation Reduction}

As perhaps the tiniest prosperous locale of the globe, it is one of the main needs of the communities is to focus on this principle goal of poverty alleviation. The allout masses of the Southern individuals is above 1600 million and a little less than half of this multitude is surviving beneath the poverty line. The illiterateness rate is about or somewhat in the rest of 50\%. The undertaking isn't transparent however 
with principle and perception for stable local teamwork, this activity can be achieved (Bhushan et al, 2002).

The $17^{\text {th }}$ SAARC Conference in 2011 agreed the most elevated require to the lightening of neediness in South Asia and cast to fortify the self-reliant South Asian delegation on Poverty Alleviation (ISACPA) which was set up in 1991 compromising of glorious people from part communities to lead an inside and out scrutiny of the assorted confrontation of representatives. The procedures for destitution lightening were recommended as the provision of health services, human resource management, access to safe drinking water and education, focusing on green growth, provision of basic needs, social welfare, and industrialization.

\section{Integrated Programme of Action (IPA)}

The above-mentioned program is a significant draft of the SAARC cycle and blends regions of sharing, each being protected by an entrusted technical board. The prestige board likewise audits the formal systems and the processing of the technical panels, their regulation, and remaining assessing the part of the bureau. The various governing councils working under the program are women empowerment, environment, communications, rural development, prevention of drug trafficking, agriculture technical board, and science and innovation.

\section{Cooperation on Financial Matters}

A significant aspect of the SAARC agenda is the meetings of SAARC finance ministers. Four conventions of SAARC finance ministers have so far been held in Bhutan (24 August 2010), Pakistan (11 July 2006), Maldives (14 May 2009), and India (15 September 2007). The First Summit of SAARC Finance Ministers affirmed the foundation of an Inter-Governmental Expert Group on Financial issues including improvement of the guide for scoring the "South Asian Economic Union (SAEU)" in an arranged way. The representatives are currently exchanging Concept Papers in the field of accounting and finance. 
As recommended by the SAARC Finance Ministers, the SAARC Expert Group on the Growth of Capital Markets in the region was also held at the SAARC Secretariat on 27 December 2011. The sixth meeting of the Inter-State trained assembly on budgeting matters occurred at the SAARC bureau on $23^{\text {th }}-24^{\text {th }}$ April in 2013. On $3^{\text {rd }}$ May 2013, the $7^{\text {th }}$ Informal summit of SAARC finance administrator occurred in New Delhi and evolvement is being organized in the constructive route of financial support while seeing new entryways for involvement and opening them.

\section{Obstacles in SAARC Growth}

There are various serious restraints that, no doubt, do not allow the growth of South Asian collaboration. It is possible to define some of these obstacles as:

\section{South Asia's Inter-state Conflicts}

Hostility, Mistrust, and shared perceptions of security are some of the major obstacles to collaboration between SAARC members. In one way or another, all members of this organization feel a threat to their territorial, economic and political stability from the neighboring economies (Weerakoon \& Sayawriya, 2002). After the removal of the colonial rulers, they are yet stuck in the ancient disputes of territorial decorum and the contested climate, i.e. lives, loss of estate, identities, and community abuse (Saboor, 2004). There are yet high uncertainties that communal and terrorist threats will disrupt cooperation efforts at any time.

\section{Fear of the Domination of India}

Another main cause of the non-success of SAARC is that there is an alarm of the supremacy position of India. India's craving to partake as a leader in the region's commanding process has yielded uneasiness among representatives, especially Bangladesh, Pakistan, and Sri Lanka (Malik, 1993). The gracious, security and political, burdens faced by SAARC representatives in the territory have hindered any encouraging development among member nations. There is segment, financial and innovative irregularity among India and different agents of the region. India 
and its neighbors have a critical exchange excess (Dawn, 2010). India's volume of casual exchange with the vast majority of its neighbors is additionally generous. Since its magnitude and position, where 80percent of the intra-local exchange South Asia is directed toward or from India, the rest members look to India to fragment their immense business sectors. India blames the mistake for SAFTA for Pakistan thus far it isn't narrow at all because SAFTA requires Sri Lanka, Pakistan, and India to bring their commitments down to 20 percent.

\section{The Clash of Civilisations}

In his book "The Clash of Civilizations" Professor Samuel Huntington said that SAARC was a disappointment because, as indicated by him, the nation's having a place with organizations such as the EU and so forth they have a place with same values yet SAARC nations are individuals whose societies are extraordinary (Jang, 2007). Pakistan and India are foes of one another, they compete on minor issues, and afterward in what capacity, in one partnership, and these two nations will assist each other. No country has any propensity to belong to the other state in the local region.

\section{The Volatility of the Financial Situation}

The weak financial circumstance of the part countries has also ended a faulty impending for this connection. This weak financial status is mirrored in the import/export imbalance amid the part countries. The Southern people are moneywise not a great deal of cutting edge. This mechanism isn't ideal for the financial progression of the territory. An enormous bit of the related countries exchange practically identical things and in that as well (The News, 2005).

This condition stimulates the most un-created countries to go for extra-territorial exchange which isn't ideal for the regionalism in the alliance. The Southern agents are not enhancing one another any way they are battling in fact. There is an extremely low shared exchange. South Asia's lower level of intra-territorial exchange has made this present association's objective a mistake. 


\section{Lack of Confidence amongst Participant Countries}

There is similar nonattendance of belief among the part nations of the territory which doesn't penetrate well for the upcoming improvement of this area affiliation. They in reality breathing in the intertwining past and shared enmities and uncertainty has affected them vast mischief as of now. The influential don't trust in everyone primarily by their zealous feelings, individual stakes, and between state questions. Inside seeing such discussions, this neighborhood affiliation can't be would have gotten a kick out of the chance to be made on stable equilibrium.

\section{Various Governmental Structures}

All the representatives' nations are having various types of governmental frameworks which is the purpose behind the disappointment of SAARC. The territory has not acted as a resilient democratic area. Like in Pakistan there is transitional democracy, in India, there is a democracy, a presidential system in Sri Lanka, and Sovereignty in Nepal. A large portion of the nations has stayed temperamental. The contest between the two nations, for example, India and Pakistan over the Kashmir issue have never let these two nations go well together and made peace on the territorial discussion. Aside from this, India is consuming debates with the rest of the part nations like Nepal, Pakistan, and Bangladesh, and Bhutan, and the indicated philosophy has not assisted SAARC targets with being accomplished.

\section{Lack of Robust Infrastructure}

Some common features are shared by South Asian economies, such as low employment, low wages, less value-added goods, and relative advantage in the same commodities such as clothes and tea, etc. Under conditions where the trade and the industrial infrastructure and economic structure are identical, intra-regional trade cannot be efficient. Almost all the member states are not economically powerful and are searching for other markets instead of intra-regional trade. About 
0.3 billion people in the region want basic services, and it is the utmost impoverished region in terms of the lack of clean drinking water for over 0.34 billion people. About 0.84 billion people do not have adequate sanitation, and 0.4 billion people go starving every day. This territory is the most militarized place in the globe, investing $\$ 30$ billion in defense costs for its two nations, India and Pakistan. Afghanistan, its new member, is faced with war. Taking into account every single serious issue, how such an association can effectively function.

\section{Policy Recommendations}

It is possible to stabilize and cement the South Asian territory if policy steps are taken with determination and confidence by South Asian leaders at government and non-government levels. As such, some of these policies and legislative measures may be proposed:

The greater part of the contentions inside South Asia are indo-focused, so India Pakistan can take a spot of safety to pick up the conviction of their more modest neighbors. Both representatives may approve specific arguments to pursue SAARC, assistance to settle the bilateral disputes. The structure of the cooperation groups could include impartiality, a delegate from each of the parties requesting group assistance, as well as one or more participants from other member countries. These groups may conduct studies of genuine issues related to human development, as well as other concerns. The SAARC Charter has to oblige consultations on the worldwide issues amongst the top of the part countries astoundingly those linking to typical issues of overall congruity, exchange, security, atmosphere and advancement moves, etc. Right now, the present arrangement doesn't contemplate such discussions with the most noteworthy point decrees being ended and made by managers quite a while formerly the finale consultation. Such a change doesn't consider these pioneers to exchange on global concerns which impact the zone generally. Take the instance of the Comprehensive Test Ban Treaty (CTBT) game plans in Geneva. Pakistan and India, anyhow their inquiry over nuclear issues had equivalent stresses over the projected CTBT. Rather than collaborating, the two countries intentionally combat shy of everyone in Geneva, debilitating total quality 


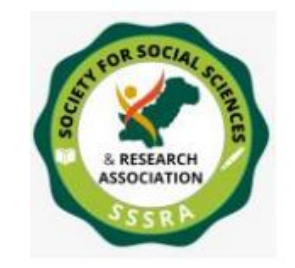

that may have aided them. SAARC, being an arising overtone and consuming the volume to join the clever markets of South Asia, have to recall for its activities to govern the reciprocal debates coolly and the procedure of selecting all the options collectively without communicating respective ones need to be free rather than wipe out (Lama, 2006). However, it would not be anything but difficult to begin so far it needs to be in progress in light of the information that except this evolution, the general improvement of this relationship is trivial (Abdullah, 2000).

By further developing rail, road, and air travel facilities, there is a need to encourage increased interaction between South Asian people. There are illustrations, no simple air associates between South Asia's major cities. To enter Colombo from Dhaka, one has to go to Bangkok. Likewise, Pakistanis ought to go to Dubai or Bangkok to arrive at Kathmandu. These down-to-earth obstructions decrease the odds of possible for individual's to-individuals connection in South Asia. An expansion in joint-adventure activities in the administration and instructive areas is the need of an hour. Further, joint-adventure activities in these areas can be one more type of individual to-individuals collaboration. To fortify the provincial monetary alliance, trade and investment actions among the neighbors of South Asia should be enlarged (Financial Express, 2006). A wide range of individuals situated associations i.e. municipal, political, and NGOs ought to take an interest to advance talks as well as trades, and participate on the road to building agreement inside the bloc for once again request in the region, in light of acknowledgment of the people's needs, allocating the mutual culture and heritage.

The exchange of scholars, poets, and other cultural circles between the countries of South Asia should be increased. Speedy admittance to one another's TV and other electronic projects ought to likewise be accessible. Arranging several more news conferences, public forum meetings, seminars, and workshops by scholars and researchers highlighting the advantages of cooperation and activation of cooperation is a dire need. Promoting exchanges through video conferences and the use of the Internet, facilities to reinforce trust-building measures that are already in place, media acts (especially the mode of electronic transmissions) to carry the folks of South Asia closer to each other. 


\section{References}

Abdullah, S. (2000). SAARC Intra-Regional Trade: As Assessment. Strategic Studies, Volume 20, No. 2 \& 3, 235-240.

Anuradha, M., \& Muni S. D. (1984).Regional Cooperation in South Asia, New Delhi: National Publishing House.

Bhargava, K. K., \& Lama M. P. (2008). SAARC 2015: Expanding Horizons and Forging Cooperation in a Resurgent Asia, New Delhi: Friedrich Ebert Stiftung.

Bhushan, K., \& Katyal, G. etal. (2002).SAARC: Challenges before New Millennium. New Delhi: A P H Publishing Corporation.

Dash K.C. (1996). The Political Economy of Regional Cooperation in South Asia, Pacific Affairs, Volume 69, No.2,186-189.

Dawn, (Pakistan) April 30, 2010.

Financial Express, (India), March 28, 2006.

Hussain, M., Islam, I., \& Kibra, R. (1999).South Asian Economic Development: Transformation, Opportunities and Challenges. London, New York: Rutledge Publishers.

Kripa,S. (2008). Regional Organizations and Conflict Management: Comparing ASEAN and SAARC, Working Paper 33 (Regional and Global Axes of Conflict), Singapore: Crisis States Research Centre, National University of Singapore,12-15. 
Lama, M. P. (2006). Political Economy of Terrorism: Sustenance Factors and Consequences. In Muni, S. D. (Ed.), Responding to Terrorism in South Asia(pp. 34-44). New Delhi: Vedams Books. Lama, M. P. (2006). SAARC: Dynamics of Emerging New Regionalism. Paper Presented at the Regional Conference on the Expansion of SAARC: Challenges and Opportunities on 29-30 June, Lalitpur: Institute of Foreign Affairs (IFA),23-27.

President PervezMusharraf"sStatement Reported by M. Aftab "Can SAFTA lead to South Asian Economic Union?'The News (Pakistan), January 19, 2004.

Rehman, S.(1999). Regional Economic Cooperation in South Asia. In Ghosh, P. K.(Ed.), A Modernization Perspective(pp. 268- 271).London: Greenwood Press.

Sabur, A.K. (2004). Regional Cooperation in South Asia: Problems of Conflict Management. Lahore: Afroze Publications.

Malik,H.(Ed.).(1993).DilemmasofNationalSecurityandCooperationinIn diaandPakistan.NewYork:St.Martin"sPress. Jang, (Pakistan), April 15,2007.

The Nation, (Pakistan), February 23, 1999

The News, (Pakistan), December 14,2007.

The News, (Pakistan), October 19, 2005.

Tonnesson S. (2004).Globalising National States. Nations and Nationalism, Volume 10, Issue 1-2,180-184. 
Weerakoon, D., \& Sayawriya, S. (2002). Economic Integration in SAARC with Special Reference to the Role of FDI in Regional Integration, Conference Paper, Dhaka: Bangladesh Institute of International and Strategic Studies (BIISS), 10-19. 